DOI 10.22460/infinity.v6i2.p195-206

\title{
LANGUAGE LITERACY AND MATHEMATICS COMPETENCE EFFECT TOWARD WORD PROBLEMS SOLVING
}

\author{
Namirah Fatmanissa ${ }^{1}$, Rahmat Sagara ${ }^{2}$ \\ ${ }^{1}$ Universitas Pendidikan Indonesia Jl. Dr. Setiabudhi No.229, Bandung. Indonesia \\ ${ }^{2}$ Institut Teknologi dan Bisnis Kalbis Jl. Pulomas Selatan. DKI Jakarta. Indonesia \\ ${ }^{1}$ namirahf@ student.upi.edu
}

Received: May 12, 2017; Accepted: July 02, 2017

\begin{abstract}
This study aims to know the effect of language literacy and basic Mathematics competence toward students' ability to solve word problems. The research was done by giving three sets of questions; language literacy (LL) set, basic Mathematics competence (BM) set, and word problems (WP) set; to the research sample. Research sample was 315 tenth grade students from five schools in Jakarta. Score of students in each set was analyzed as research data. Score of LL set was treated as data of independent variable 1, score of BM set was treated as data of independent variable 2, and score of WP set as data of dependent variable. Preliminary data analyses, such as normality, validity, and reliability test, were done. Then, data was analyzed using Wilcoxon test and calculation of R-square. The result shows that each of independent variable affects dependent variable with BM variable has more effect on WP variable. It is expected that in solving word problems, the way students use their basic mathematical competencies is supported together with their ways of using language literacy.
\end{abstract}

Keywords: Basic Mathematics Competence, Language Literacy, Word Problem.

\begin{abstract}
Abstrak
Penelitian ini bertujuan untuk mengetahui pengaruh kecakapan bahasa dan kemampuan dasar Matematika terhadap kemampuan siswa dalam menyelesaikan soal cerita. Penelitian dilakukan dengan memberikan tiga paket soal, yaitu paket soal kecakapan bahasa (KB), kemampuan dasar Matematika (KDM), dan kemampuan soal cerita (KSC)kepada sampel penelitian. Sampel penelitian ini adalah siswa kelas X dari satu sekolah di setiap area di Jakarta, yaitu Jakarta Utara, Jakarta Selatan, Jakarta Barat, Jakarta Timur, dan Jakarta Pusat. Dari lima sekolah tersebut diperoleh sampel penelitian berukuran 315 siswa. Data yang dianalisis adalah nilaiyang diperoleh siswa pada tiap paket soal. Data nilai untuk paket soal KB sebagai data variabel independen pertama, data nilai untuk paket soal KDM sebagai data variabel independen kedua, dan data nilai untuk paket KSC sebagai data variabel dependen. Hasil uji Wilcoxon menunjukkan bahwa variabel independen berpengaruh terhadap variabel dependen, dan dari nilai R-Kuadrat didapatkan bahwa variabel KDM memiliki pengaruh yang lebih besar terhadap variabel KSC. Dalam menyelesaikan soal cerita, diharapkan siswa dapat didukung dalam menggunakan kemampuan dasar Matematikanya sekaligus dengan kecakapan bahasanya.
\end{abstract}

Kata Kunci: Kecakapan Bahasa, Kemampuan Dasar Matematika, Soal Cerita.

How to Cite: Fatmanissa, N., \& Sagara, R. (2017). Language Literacy and Mathematics Competence Effect Toward Word Problems Solving. Infinity, 6 (2), 195-206. doi:10.22460/infinity.v6i2.p195-206 


\section{INTRODUCTION}

Mathematics is an essential knowledge and its application is used in almost all branches of science. In Indonesia education, Mathematics is one of knowledge that should be mastered by all students. The purpose of this mastery is to make students use Mathematics as a tool to understand daily life (Conway \& Sloane, 2005).

Education world nowadays has realized students' reluctance on understanding Mathematics. The reason behind this case is that Mathematics is considered as collection of formulas and rigid, abstract procedures that is hard to be understood (Schwanebeck, 2008). Students argue that Mathematics is not important for their life and it is enough to be learned by students who are indeed capable of it. However, in fact, Mathematics is integrated deeply in every aspect of life (Gouthro \& Griffore, 2004).

Due to that reason, Mathematics learning in the class is aimed not only to make students understand its concept, but also to apply it in life (Gouthro \& Griffore, 2004). Learning process in the class should relate Mathematics materials to its use in solving daily problems. In other words, the lesson objectives are not the mastery of Mathematics numerical operations, but also the mastery of solving problems related to real life. In this case, word problem become one of the tools to assess students ability in solving such problem.

Word problem is generally defined as collection of words and structures which creates a problem. Specifically, word problem has several characteristics that make it more complicated compared to other forms of problem. The first characteristic is that word problem is contextual, which means it contains elements exist in daily life. Word problem offers daily life problem which should be solved by students by using Mathematical approach. The second characteristic is that word problem needs not only one single step to solve it.

One of the ways to make students able to apply Mathematics in daily life is by optimizing their ability in solving word problems because through word problems, students can grasp the concrete feeling of Mathematics (Lave, 2016). However, in Indonesia, students' ability to solve word problems are considered to be low (Rindyana \& Chandra, 2012; Huda \& Kencana, 2013; Sutarni, 2011). PPPPTK for Mathematics, Center for the development and empowerment of teachers and educational staff in Indonesia, stated that over $50 \%$ of Indonesian teachers complaint about the difficulties of students in solving word problems. Rindyana \& Chandra (2012) found that this problem was due to the lack of understanding of the meaning of words contained in the problems. They found that more than $84 \%$ of students being studied did not understand the meaning of words and/or did not know the purpose of the question. Sutarni (2011) addressed the same focus by finding that students being studied were not accustomed to read carefully and thus resulting on the lack of ability to solve word problems. Huda \& Kencana (2013) addressed different aspect by finding that the low ability was due to the lack of mathematical concept understanding.

To optimize the ability to solve word problems, the knowledge of factors influencing students' ability to solve word problems is needed.If a student is given a word problem and cannot answer it correctly, here come a question whether this student cannot answer the problem due to his/her inability to understand the context of word problem and thus cannot construct steps to solve it, or due to his inability to do the steps to get the answer although he/she understands the context. This question leads to the discussion of factors influencing students' ability to solve word problems. 


\section{Language Literacy Factor}

Language literacy is one's ability to read, write, speak, and listen to reach a particular purpose. Related to word problem, the abilities being used are reading and writing ability. Reading ability is the ability to understand meaning of collection of written letters and words. While writing ability is the ability to express what is known and what is needed to be delivered in a written form. Language literacy, the ability to read and write, is used when students read the word problem, understand it, and then write its Mathematical model.

Gardner (2004) highlighted students' language literacy as verbal-linguistic intelligence, one of eight intelligences in his Multiple Intelligences theory. Gardner said that one's language literacy could be seen from four aspects. They are convincing someone that information is true, reminding someone of an information, explaining something, and reflecting idea to another form of language.

In solving word problem, aspect of explaining something and reflecting an ideato another form become important. Aspect of explaining something consists of how someone expresses and understands some information either orally or written. In relation with word problem, this aspect is shown when student tries to understand the word problem. When student reads the written word problem, the process of changing written material to information stored in the brain happened. Whereas aspect of reflecting idea consists of how someone changes information become another form with the same meaning. This aspect is contained in the process of making Mathematical model from written sentences of word problem. A correct reflection process will result on Mathematical model which has the same meaning with the sentences in the problem. Without an accurate model, there may be mistakes in the next stages of solving problem. Because of that, students' lack of language literacy may cause misinterpretation of the meaning and purpose of the given word problem.

Context understanding that is necessary in solving word problem was analyzed by Clement (2008) who stated that students with difficulty in solving word problems tend to question the meaning of the problem or discuss its interpretation. Clement also said that students who failed to correctly answer word problem were mostly the ones who did not pay attention to its context, but directly did the Mathematical operation that they considered to be appropriate. These statements show that language literacy, which is indicated by information and context understanding, is the factor that is needed to be examined in order to escalate students' ability in solving word problems.

Lee (2006) stated that in understanding written information, there are two things should be put into concern, vocabularies and syntax or sentence structure. In Mathematical text, vocabularies are very varied. Kersaint, Thompson, \& Petkova (2014) had similar opinion with Lee that vocabularies in Mathematics could be classified into vocabulary that has similar meaning with daily words and vocabulary that has different and specific meaning with its daily usage. Vocabulary such as limit, supplementary, and positive have different meanings between their use in Mathematical text and in daily usage. While vocabulary like smaller than, addition, and greater than have the same meanings both in daily life and Mathematical text. The ability to understand the difference and similarity of vocabulary meaning has role in one's language literacy. 
The understanding of syntax or sentence structure is also an important factor. People often use active voice in daily conversation, while in fact Mathematical text mostly uses passive voice rather than active voice (Kersaint, Thompson, \& Petkova, 2014). In active voice sentence, subject of the sentence is stated clearly, while in passive voice sentence, sentence subject is not stated explicitly. Mathematical text that has passive voice structure demands someone to adjust his/her understanding of active to passive voice, which make understanding Mathematical text more difficult.

\section{Basic Mathematics Competence Factor}

Gardner (1999) defined logic-mathematics ability as an ability of someone to analyze problem logically, do mathematical operation, and do scientific inquiries. These abilities are needed in solving word problems.

This is inline with Piaget's cognitive development theory. Piaget explained that students mathematics competence develops gradually through four development stages i.e. sensorimotor, pre-operational, concrete operation, and formal operation. In the second and last stages lies the relation between basic mathematics competence and ability to solve word problems.

On pre-operational stage, student is only able to solve problem using one step (Ojose, 2008). Concerning the complex steps of solving word problems, in this stage student is only able to do procedural calculating operation. On concrete operation stage, student can convert real life Mathematics problem into symbols and Mathematics equations (Moursund, 2007). On solving word problems, this stage shows "plan" process when students try to design strategy to solve problems. Whereas on the last stage, formal operation stage, student can do process of abstraction (Moursund, 2007). Students are able to understand abstract concepts without involving concrete example of the concept.

From this discussion, it is known that basic mathematics competence can be monitored from pre-operational stage. This is because student does not do process of converting information from concrete (real life context) to abstract (Mathematics symbols and equations), but only organizing information provided using mathematical operation.

Beside cognitive development, basic mathematics competence is also related to the topics or branches of mathematics that are tested in word problems. Basic mathematics competence is identified from branches which are the foundation of other branches. One of these is arithmetic. Arithmetic has been agreed as a fundamental branch and foundation of mathematics (Marjanović, 1999). Beside arithmetic, logic is also a fundamental branch of mathematics. This is because logic is used in almost all reasoning of other mathematics branches concepts or known as logical reasoning. Together with arithmetic and logic, algebra becomes the basic of mathematics learning content. Algebra contains fundamental principles in solving word problems (Wilson, 2009). Another branch to be considered, as Niss (1998) said to have important role in mathematics learning as shown on the number of research discussing reasoning of its concept and role in daily life, is Geometry.

\section{Other Factors}

One of other factors that is considered to affect the process of solving word problems is level of difficulty. Level of difficulty can be seen from two aspects. First is the use of syntax or term and word preference in the problem (Xin, 2007). The more complex and unfamiliar the 
word for the students, the more difficult for students to interpret the objective of the problem and the greater possibility for students to obtain wrong information. Second is the existence of element that has been learnt by students before. The more difficult the element to be recognized, the more difficult students catch the information correctly.

Beside level of difficulty, students' perception toward word problem is considered affecting the ability to solve word problems (Schwanebeck, 2008). Students perhaps are reluctant to answer the question because of the topic of the word problem is not what they like.

If compared with other factors mentioned, language literacy factors (which is the ability to read and write) and basic mathematics factor are the key role in the process of mathematics solving. Larwin (2010) compare language literacy with confidence, teacher's expectation, and the use of technology in affecting students' score in a test that is dominated with word problems. Language literacy has the biggest effect among other factors. Larwin even stresses that students' low language literacy should be addressed after being known by teacher because this issue may hamper students' learning in the next stages. Schoppek \& Tulis (2010) stated that basic mathematics competence, compared to motivation, gives more significant impact to solving word problems. Beside that, basic mathematics competence and language literacy are two factors that are always involved in every word problem solving process (Seifi, Haghverdi, \& Azizmohamadi, 2012). These two factors is contained in each strategy of solving problems and determine whether the strategy is appropriate or not.

It is already elaborated that solving word problems is affected by many factors in which two among them (language literacy and basic mathematics competence) are the most significant factor. These two factors are then analyzed to know their effect on students' ability in solving word problems.

Some literatures have mentioned the relationship between language literacy and basic mathematics competence and solving word problems. Sammons (2011) stated that these three aspects are supporting each other. If one aspect is sufficient, then other aspects will be sufficient and improved, too. Language literacy and basic mathematics competence have strong relation with word problem solving (Schoppek \& Tulis, 2010). These two aspects are involved in important points in the process of word problem solving, thus the effect is enormous in determining the success of students in solving word problem.

Based on Vilenius-Tuohimaa, Aunola, \& Nurmi (2008), language literacy is one of the factors that determine the success of someone in solving word problems. Through his research, it is found that language literacy and the ability to solve word problems have strong positive correlation. An exemplary language literacyis indicated with exemplary ability in solving word problems. In solving word problems, process of absorbing information from written texts happened (OECD, 2011). This process is needed to design a plan on how to solve particular word problem. Language literacy takes important role in this part because language literacy determines whether student has chosen appropriate information from the given word problem. Awofala, Balogun, \& Olagunju (2011) strengthened this statement by comparing low language literacy students with high language literacy in solving word problems. The result was that the students who have high language literacy was significantly more excellent in solving Mathematics word problems.

Basic mathematics competence is also an unavoidable criteria in solving word problems (Sammons, 2011). The knowledge of mathematical procedure determines how students 
process information obtained from word problem accurately and efficiently. Besides, Geary (2000), in his research that studied the development of Mathematics basic competence of an individual from pre-school to adult and its relation with solving word problems, stated that the development of basic Mathematics competence of an individu would significantly help his/her development in solving word problems. Geary also stated that basic competences such as numerical operation, together with language literacy, affected the ability to solve word problems, regardless the age.

\section{METHOD}

Sample of the research was 315 senior high school students of grade 10 in greater Jakarta area, Indonesia. The participants were taken from one school in each Jakarta region, i.e. North, South, West, East, and Central Jakarta. More detail information of participants was given in Table 1 .

Table 1. Number of Participants in Each Region

\begin{tabular}{lc}
\hline Region & Number of participants $\left(\boldsymbol{n}_{\boldsymbol{i}}\right)$ \\
\hline North Jakarta & 56 \\
South Jakarta & 45 \\
West Jakarta & 65 \\
East Jakarta & 90 \\
Central Jakarta & 59 \\
TOTAL & 315 \\
\hline
\end{tabular}

Data was taken using three sets of test given to participants and each test represented particular variable. Score for language literacy (LL) test as independent variable 1, score for Basic Mathematics competence (BM) test as independent variable 2, and score for word problem (WP) test as dependent variable.

Basic Mathematics (BM) test was developed based on four dimensions which were arithmetics, algebra, geometry, and logic. Language literacy (LL) test was developed based on three dimensions which were same-meaning words, different-meaning words, and syntax. Word problems test was developed with four dimensions which were word problems on algebra, arithmetics, geometry, and logic. Each test consisted of 10 questions with the expansion of each dimension could be seen in Table 2.

Table 2. Dimension Expansion

\begin{tabular}{ccc}
\hline Variable & Dimension & Question no. \\
\hline $\mathrm{BM}$ & Algebra & $3,4,5$ \\
& Geometry & 6,7 \\
& Arithmetic & 1,2 \\
& Logic & 9,10 \\
\hline LL & Same-meaning words & $5,6,9,10$ \\
& Different-meaning words & $1,2,7$ \\
& Syntax & $3,4,8$ \\
\end{tabular}




\begin{tabular}{ccc}
\hline Variable & Dimension & Question no. \\
\hline WP & Algebra & $4,5,6$ \\
& Geometry & 7,8 \\
& Arithmetic & $1,2,3$ \\
& Logic & 9,10 \\
\hline
\end{tabular}

Beside those dimensions, the test was controlled by varying level of difficulties of the questions. In 30 questions, there are easy, medium, and hard question. The level of difficulty was determined by how complex the steps needed to solve it. Besides, for LL test, the level of difficulty was determined by how complex the words and syntax that were in the question. In WP test, the combination between those two elements became the cause of difficulty level. Table 3 showed the level of difficulty of each question.

Table 3. Level of Difficulty of Each Question

\begin{tabular}{|c|c|c|c|}
\hline \multirow{2}{*}{ Level of difficulty } & \multicolumn{3}{|c|}{ Question no. } \\
\hline & $\mathbf{B M}$ & $\mathbf{L L}$ & WP \\
\hline Easy & $1,3,9$ & $1,5,7$ & $1,3,5,9$ \\
\hline Medium & $2,5,7,6$ & $2,3,6,9$ & $2,4,7,10$ \\
\hline Hard & $4,8,10$ & $4,8,10$ & 6,8 \\
\hline
\end{tabular}

After all 30 questions had been developed and underwent several revisions, the test was given to participants. The participants were given three sets of test with break time in between. The break time was given to reduce the boredom or stress happened during test taking. The test was given with the following order; LL test continued by break time, then continued by BM test and break time, and last test was WP test. Participants of the test were not allowed to discuss the question with anyone and use calculator or other calculating tools during the test. The scheme of the test was given in Figure 1.

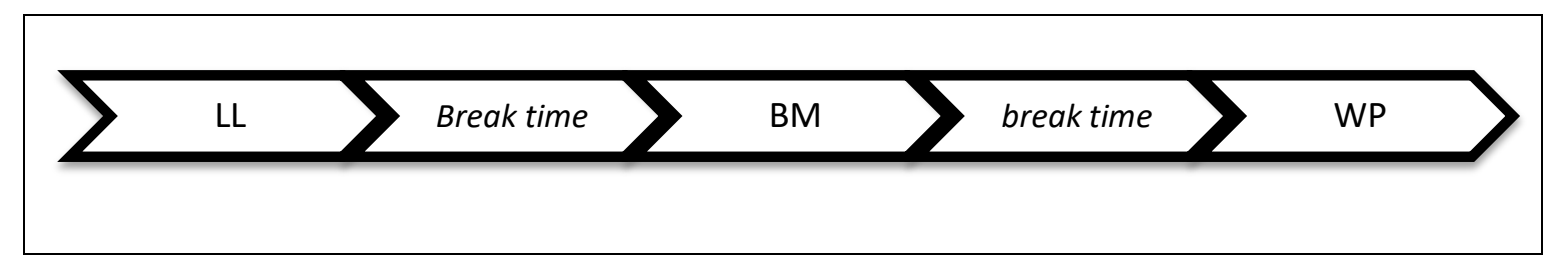

Figure 1. Test Scheme

After the test, students' work were evaluated and graded. Each correct final answer was scored 1, and 0 for wrong answer. The score was given for each test, thus student who got perfect score was the one who got 10 in each test.

\section{RESULTS AND DISCUSSION}

Initial data analysis showed four outliers and these were not considered during further analysis. Normality test showed that data distribution was not normal. Validity test showed that one question in LL test was not valid and then were not included in analysis. Reliability test showed that each test was reliable with Alpha-Cronbach coefficient of 0.812 . 
Some participants could answer the questions correctly, but some could not. The information of number of students having correct answer was given in Table 4.

Table 4. Number of Students Having Correct Answer

\begin{tabular}{|c|c|c|c|c|c|c|c|c|}
\hline \multirow{2}{*}{$\begin{array}{l}\text { BM } \\
\text { no. }\end{array}$} & \multicolumn{2}{|c|}{$\begin{array}{l}\text { Students answered } \\
\text { correctly }\end{array}$} & \multirow{2}{*}{$\begin{array}{l}\text { LL } \\
\text { no. }\end{array}$} & \multicolumn{2}{|c|}{$\begin{array}{l}\text { Students answered } \\
\text { correctly }\end{array}$} & \multirow{2}{*}{$\begin{array}{l}\text { WP } \\
\text { no. }\end{array}$} & \multicolumn{2}{|c|}{$\begin{array}{c}\text { Students answered } \\
\text { correctly }\end{array}$} \\
\hline & $\mathbf{n}_{\mathbf{j}}$ & $\%$ & & $\mathbf{n}_{\mathbf{j}}$ & $\%$ & & $\mathbf{n}_{\mathbf{j}}$ & $\%$ \\
\hline 1 & 243 & 77.14 & 1 & 247 & 78.41 & 1 & 257 & 81.59 \\
\hline 2 & 261 & 82.86 & 2 & 237 & 75.24 & 2 & 260 & 82.54 \\
\hline 3 & 132 & 41.90 & 3 & 300 & 95.24 & 3 & 105 & 33.33 \\
\hline 4 & 136 & 43.17 & 4 & 287 & 91.11 & 4 & 157 & 49.84 \\
\hline 5 & 190 & 60.32 & 5 & 292 & 92.70 & 5 & 139 & 44.13 \\
\hline 6 & 60 & 19.05 & 6 & 164 & 52.06 & 6 & 60 & 19.05 \\
\hline 7 & 173 & 54.92 & 7 & 243 & 77.14 & 7 & 106 & 33.65 \\
\hline 8 & 98 & 31.11 & 8 & 212 & 67.30 & 8 & 205 & 65.08 \\
\hline 9 & 214 & 67.94 & 9 & 302 & 95.87 & 9 & 247 & 78.41 \\
\hline 10 & 11 & 3.49 & 10 & 141 & 44.76 & 10 & 226 & 71.75 \\
\hline Mean & 151.8 & 48.19 & Mean & 242.5 & 76.98 & Mean & 176.2 & 55.94 \\
\hline
\end{tabular}

In average, each question of LL test was answered correctly by $76.98 \%$ students. This was the highest percentage compared to BM test (48.19\%) and WP test (55.94\%). Besides, the average students' score on BM test was also shown as the highest. The score of students in LL test had the lowest variance. Descriptive statistics of each test were given in Table 5 below.

Table 5. Descriptive Statistics of Each Test

\begin{tabular}{lccc}
\hline & BM & LL & WP \\
\hline Mean & 4.819 & 7.698 & 5.594 \\
Highest score & 10 & 10 & 10 \\
Lowest score & 0 & 2 & 0 \\
Standard deviation & 2.353 & 1.676 & 2.284 \\
Variance & 5.537 & 2.81 & 5.217 \\
\hline
\end{tabular}

“Did basic Mathematics competence and language literacy affect students' ability in solving word problems?"

To answer this question, there were three numerical data to be analyzed, which were BM test score as 1 st independent variable, LL test score 2 nd independent variable, and WP test score as dependent variable. Knowing the fact that the data is not normally distributed, Wilcoxon test was used. In Wilcoxon test, there were two separated tests. The first test checked whether BM variable affected WP variable, while the second test checked whether LL variable affected WP variable. In Wilcoxon test, null $\left(\mathrm{H}_{0}\right)$ and alternative $\left(\mathrm{H}_{1}\right)$ hypothesis as follow.

$\mathrm{H}_{0}$ : relative frequency distribution for both variables were identical;

$\mathrm{H}_{1}$ : independent variable made the relative frequency distribution of dependent variable shifted; or independent variable affected the dependent variable. 
The result of Wilcoxon test run by SPSS was given in Table 6.

Table 6. Wilcoxon Test Result

\begin{tabular}{lcc}
\hline & BM toward WP & LL toward WP \\
\hline $\mathrm{n}$ & 311 & 311 \\
Test Statistic & $25,091.000$ & $25,984.000$ \\
Standard error & $1,229.752$ & $1,160.814$ \\
Sig. & .000 & .000 \\
\hline
\end{tabular}

From Wilcoxon test, with $\alpha=5 \%$, it was known that both the first and second test showed rejection to null hypothesis. This means that, with significance level of $5 \%$, basic mathematics competence and language literacy had significantly affected the ability to solve word problems.

Related to this, some examples of student's written work were found. For example in the question of, "Two kids can dye a wall in 5 hours. How long does it take for 3 kids to dye that wall?" Several students' answers were like given in Figure 2. The answer given in Figure 2 showed that students did understand the question, however failed to use proper mathematical concept to give correct answer.

5. Dua anak dapat mengecat suatu tembok dalam 5 jam. Berapa lama waktu yang dibutuhkan oleh 3 anak untuk mengecat tembok tersebut?
$2 \rightarrow 5$
$3 \rightarrow$
$\frac{3}{2} \times 5=\frac{15}{2}=7.5 \mathrm{jam}$

Figure 2. Sample of Students' Answer

Some others, show the lack of understanding of question aim. Student's answer given in Figure 3 was the example. The question given was "Ani sucks 5 times and gulps 4 times to consume a glass of milk. While to consume 2 glasses of milk, she sucks 13 times and gulps 7 times. So, one Ani's gulp equals how many suck?". The student's answer showed that he could not understand words representing variables. He simply consecutively put numbers given in the question into mathematical model, and could not complete his work.

6. Ani menyedot 5 kali dan meneguk empat kali untuk menghabiskan segelas susu. Sedangkan untuk menghabiskan 2 gelas susu, ia perlu menyedot 13 kali dan meneguk 7 kali. Maka satu tegukan Ani setara dengan berapa sedot?

$56+4 y=1 \quad 106+84=2$

$2 \varphi+13 y=7 \quad \frac{16 e+5 y=75}{57 y=33}$

Figure 3. Sample of Students' Answer 
While students in Figure 2 failed to give correct answer because of the lack of mathematical concept understanding, students in Figure 3 failed because of the lack of understanding words role in representing variables.

\section{"If those have effect, which one did give greater effect toward the ability to solve word problems? Basic Mathematics competence or language literacy?"}

It had been known that basic mathematics competence (BM) and language literacy (LL) had significantly affected the ability to solve word problems (WP). An analysis to answer the second question was by determining R-square value for each variable. SPSS output of each variables' R-square was given in Table 7.

Table 7. R-Square Value of BM and LL Toward WP

\begin{tabular}{lll}
\hline & BM & LL \\
\hline $\mathrm{R}$ & .544 & .410 \\
R-square & .296 & .168 \\
Sig. & .000 & .000 \\
\hline
\end{tabular}

Based on Table 7, BM variable can explain $29.6 \%$ variance of WP variable, while LL variable can explain $16.8 \%$ variance of WP variable. From this fact, it can be inferred that BM variable had more effect compared to LL variable. In other words, the ability of student in solving word problem was slightly more determined by basic mathematics competence than by language literacy although both correlations actually considered as low.

The fact that basic Mathematics competence has more role in affecting the ability to solve word problem is not inline with the initial hypothesis that both variables have equal effect. This leads to a question that several studies (Geary, 2000; Schoppek \& Tulis, 2010, Larwin, 2010) support the initial hypothesis. It cannot be denied that the referred studies have different contexts compared to this study. The type of sample, for example in Geary (2000), has great range of age, has its own inferences compared to this study in which all participants are in the same age.

Theoretically, language literacy and basic mathematics competence are not the only factors in determining the ability to solve word problems. The existence of other factors can affect the "sharing" of impact towards the ability to solve word problems. For example in Schwanebeck (2008) who stated that solving problems cannot be separated from other factors beside language literacy and basic mathematics competence, for example emotional aspect of students.

The number of questions or problems given in this study has met or represented the dimensions. However, by adding the number of questions, the variety of question type and level of difficulty might increase thus the data will be more varied. The conclusion given in this study did not answer a more detailed question like, "How do students use his/her language literacy in solving word problems?". Because of that, this study can be expanded into a qualitative approach. 


\section{CONCLUSION}

Both Basic mathematics competence and language literacy affect the ability of students in solving word problems. Compared to language literacy, basic mathematics competence has more effect in determining that ability. Teachers should pay more attention to how students solve word problems in terms of how they use their mathematics competences (e.g. calculating, using algorithm, etc) and also how they use their language literacy (e.g. understanding the problem, giving meaning to words, etc). In the context of word problems discussion, teachers are expected to discuss why certain information transformed into certain mathematical model. The process of understanding mathematical words that are used in problems and then interpreting them cannot be neglected as language literacy also contributed in this process.

Besides, word problems are one of the ways in knowing students higher order thinking. If teacher wants to improve students higher order thinking, they can intensify the use of word problems. Students are expected not too focused on memorizing formula and rigid procedures. They were expected to pay attention to their mathematics competence without neglecting their ability to make meaning and understanding written information given in the word problems.

\section{REFERENCES}

Awofala, A. O., Balogun, T. A., \& Olagunju, M. A. (2011). Effects of three modes of personalisation on students' achievement in mathematical word problems in Nigeria. International Journal for Mathematics Teaching \& Learning.

Clement, J. J. (2008). Does Decoding Increase Word Problem Solving Skills?.Northeast: University of Nebraska-Lincoln accessed onMarch $5^{\text {th }}, 2013$ from scimath.unl.edu/MIM/files/research/SlackJ.pdf.

Conway, P \& Sloane, F. C. (2005). International trend in post-primary mathematics education: Perspectives on learning, teaching and assessment. Washington DC: NCCA.

Gardner, H. J. (1999). Intelligence Reframed: Multiple Intelligences for $21^{\text {st }}$ century. New York: Basic Book.

Gardner, H. J. (2004). Frames of Mind: The theory of Multiple Intelligences. New York: Basic Book.

Geary, D. C. (2000). From infancy to adulthood: The development of numerical abilities. European child \& adolescent psychiatry, 9, S11-S16.

Gouthro, M, \& Griffore, J. (2004). Leading Math Success: Mathematical Literacy. Ontario: $\begin{array}{llll}\text { Ontario Education, Accessed on November } 16^{\text {th }}, & 2011\end{array}$ fromhttp://oame.on.ca/lmstips/files/lms/LeadingMathSuccess.pdf

Huda, N., \& Kencana, A. G. (2013). Analisis Kesulitan Siswa Berdasarkan Kemampuan Pemahaman dalam Menyelesaikan Soal Cerita pada Materi Kubus dan Balok Di Kelas VIII SMP Negeri 30 Muaro Jambi. Prosiding SEMIRATA 2013, 1(1).

Kersaint, G., Thompson, D. R., \& Petkova, M. (2014). Teaching mathematics to English language learners. Routledge.

Larwin, K. H. (2010). Reading is Fundamental in Predicting Math Achievement in 10th Graders?. IEJME-Mathematics Education, 5(3), 131-145 
Lee, C. (2006). Language for Learning Mathematics: Assessment for Learning in Practice. New York: Open University Press.

Lave, J. (2016). Word problems: a microcosm of theories of learning. (2016). Context and Cognition: Ways of Learning and Knowing. London: Routledge.

Marjanović, M. M. (1999). A Broader way Through Themas of Elementary School Mathematics, II. The teaching of mathematics, (3), 81-103.

Moursund, D. (2007). Computational Thinking and Math Maturity: Improving Math Education in $K-8$ Schools ( $2^{\text {nd }} E d$.). Oregon: University of Oregon.

Niss, M. (1998). Teacher qualifications and the education of teachers. In Perspectives on the Teaching of Geometry for the 21st Century (pp. 297-318). Springer Netherlands..

Organisation for Economic Co-operation and Development (OECD). (2011). The PISA 2003 Assessment Framework-Mathematics, Reading, Science, and problem solving knowledge and skill. Paris: OECD Publishing

Ojose, B. (2008). Applying Piaget's Theory of Cognitive Development to Mathematics Instruction.Journal of Mathematics Educator, 18(1), 26-30.

Rindyana, B. S. B., \& Chandra, T. D. (2012). Analisis Kesalahan Siswa Dalam Menyelesaikan Soal Cerita Matematika Materi Sistem Persamaan Linear Dua Variabel Berdasarkan Analisis Newman (Studi Kasus MAN Malang 2 Batu). Artikel Ilmiah Universitas Negeri Malang.

Sammons, L. (2011). Building Mathematical comprehension: Using literacy strategies to make meaning. Huntington Beach: Shell Education

Schwanebeck, T. (2008). A study of summarization of word problems. Nebraska: University of Nebraska.

Seifi, M., Haghverdi, M., \& Azizmohamadi, F. (2012). Recognition of students' difficulties in solving mathematical word problems from the viewpoint of teachers. Journal of Basic and Applied Scientific Research, 2(3), 2923-2928.

Schoppek, W., \& Tulis, M. (2010). Enhancing arithmetic and word-problem solving skills efficiently by individualized computer-assisted practice. The Journal of Educational Research, 103(4), 239-252..

Sutarni, M. (2011). Penerapan metode mind mapping dalam meningkatkan kemampuan mengerjakan soal cerita bilangan pecahan. Jurnal Pendidikan Penabur, 1(16), 26-33.

Vilenius-Tuohimaa, P. M., Aunola, K., \& Nurmi, J. E. (2008). The association between mathematical word problems and reading comprehension. Educational Psychology, 28(4), 409-426.

Wilson, W. S. (2009). Elementary school mathematics priorities. AASA Journal of Scholarship \& Practice, 6(1), 40-49.

Xin, Y. P. (2007). Word problem solving tasks in textbooks and their relation to student performance. The Journal of Educational Research, 100(6), 347-360. 